\title{
Pyrolytic Extraction and Characterization of Oil from Waste Recharge Scratch Card Papers for Industrial Application
}

\author{
Jock Asanja Alexander ${ }^{1}$, Okoli Christian Sunday ${ }^{1}$, Hamidu Lucas Albert Jerome ${ }^{2}$, \\ Daben Moses Janet ${ }^{3}$, Peters Grace Funmilayo ${ }^{3}$
}

${ }^{1}$ University of Uyo

Ikpa Road, P. M. B. 1017, Akwa Ibom Ibom State, Nigeria

${ }^{2}$ Nigerian, Building, and Road Research Institute

Idiroko Road, P. M. B 1055, Ota, Ogun State, Nigeria

${ }^{3}$ University of Jos

P. M. B 2084, Jos, Nigeria

DOI: $10.22178 /$ pos. $62-15$

LCC Subject Category: TP315-360

Received 19.08.2020

Accepted 25.09.2020

Published online 30.09 .2020

Corresponding Author:

Jock Asanja Alexander

alsanja@gmail.com

(C) 2020 The Authors. This article is licensed under a Creative Commons Attribution 4.0 License @ (1)

\begin{abstract}
Oil extracted from mobile phone waste recharge scratch cards paper by thermal pyrolysis was investigated. The oil was characterized by its physical, chemical, and functional groups present. The physicochemical characteristics of the oil determined are density $900 \mathrm{~kg} / \mathrm{m}^{3}$, viscosity $1.5 \mathrm{~mm}^{2} \mathrm{~s}^{-1}$, acid value $1.122 \mathrm{mgKOH} / \mathrm{g}$, saponification value $98.175 \mathrm{mgKOH} / \mathrm{g}$ and iodine value $22.84 \mathrm{gl}_{2} / 100 \mathrm{~g}$. The pour point and flashpoints are $-15^{\circ} \mathrm{C}$ and $90{ }^{\circ} \mathrm{C}$ respectively. The Fourier Transform Infrared (FTIR) and Gas Chromatography-Mass Spectroscopy (GC-MS) revealed the presence of aldehydes, ketones, carboxylic acids, esters, alkenes alkanes, ethers, and phenol. This indicates that the oil has industrial applications in chemical, pharmaceutical, and biodiesel production.
\end{abstract}

Keywords: bio-oil; biomass; pyrolysis; physiochemical.

\section{INTRODUCTION}

Pyrolysis is the thermal conversion of organics in the absence of oxygen. It is a promising and environmentally friendly way of energy recovery from biomass as biomass is the only renewable source of fixed carbon. However, among the thermochemical conversion methods, pyrolysis is the most suitable method to produce bio-oil as the main product [19].

Bio-oil obtained by the pyrolysis of biomass is thus emerging as an alternative source of sustainable energy for diesel engines, gas turbines, heating applications, and for use as a chemical feedstock [11]. Bio-oils are highly oxygenated, complex mixtures, viscous, relatively unstable, susceptible, corrosiveness, and poor heating value may present some difficulties on their direct use as conventional fuels [13].
In the pyrolysis process, the volatile components condense to bio-oil or can be subjected to further treatment and processes to produce secondary products such as higher value and quality fuel or chemical products [17]. Biomass utilization gives the possibility of generating value-added products such as chemicals or activated carbons, which means an attractive economic and technological solution [15]. Lignocellulosic biomasses have tremendous potentials in the production of fuels and chemicals. These materials are available in surplus worldwide and do not compete with the food supply [21].

The most important component obtained during pyrolysis is pyrolysis oil. The organic compounds of bio-oil are acids, alcohols, aldehydes, esters, ketones, sugars, phenols, phenol derivatives, and a large proportion of lignin-derived oligomers [7]. Bio-oils are composed of differently sized molecules derived primarily from the 
depolymerization and fragmentation reactions of three key biomass building blocks, i.e., cellulose, hemicellulose, and lignin, resulting in its composition and properties of considerable difference from those of petroleum-based fuel oils [24].

In recent years, the research on bio-oil has been paid more attention due to the property of sustainable, carbon-neutral, and easy to store and transport. Series of methods such as pyrolysis, liquefaction, gasification, hydrotreatment, etc, are developed to prepare and upgrade bio-oil. Pyrolysis is the more efficient method and the pyrolysis process conditions can be optimized to maximize the production of liquids (tar, bio-oil), solids (char), or gases whose distribution depends on the experimental conditions applied especially temperature and heating rate [9].

Pyrolysis has proved itself to be a new type of solid biomass and waste utilization technique that transforms biomass and waste material of lowenergy-density into bio-oil of high-energy-density and recover higher-value chemicals. The maximum bio-oil yield of pyrolysis products from the waste paper of $49.13 \%$ was achieved at $420{ }^{\circ} \mathrm{C}$ and the spectroscopic and chromatographic analysis revealed that bio-oil contained many different chemical classes with anhydrosugars, carboxyl compounds, carbonyl compounds, and aromatic compounds are the four main different compounds in bio-oil [5].

The chemical constituent of biomass contains a different proportion of cellulose, hemicellulose, and lignin substrate. The biomass substrate which contains a greater proportion of lignin derivatives can yield more bio-oils yield [25].

The biomass fast pyrolysis is attractive because the biomass can be readily converted into liquid products. These liquids, such as crude bio-oil, have advantages in transport, storage, combustion, retrofitting as well as flexibility in production and marketing [23].

Recharge card is one of the fastest-selling Global systems for mobile communication (GSM) in most developing countries, especially in Nigeria. Recharge cards are basic top-ups on mobile phones (for calls), tablets, computers, and modems (for internet connection subscription). The printing and usages of recharge vouchers for all networks (MTN, AIRTEL, GLO, ETISALAT, etc.) in Nigeria are increasing because of the high rate of user demand. However, these mobile phone recharge cards have not received the needed safety watch and attention on the danger it likely poses on the environment [10]. Similarly, commercial available recharged cards in Nigeria are silver coated which is of a health hazard on humans and living creatures due to contamination with heavy metals [2].

This study was aimed at pyrolytic extraction and characterization of oil from mobile phone recharged cards for industrial applications. The recharged cards were selected for this research because it has the potential for bio-oil and bio-chars. Also, the disposal of waste scratch cards paper may cause environmental pollution.

\section{MATERIALS AND METHODS}

Sample collection and preparation. Waste recharge card samples were collected from local recharge card vendors within the University of Jos Community. The samples were sun-dried for 48 hrs, cleaned using cotton wool to remove dust particles, and shredded to smaller sizes.

Pyrolysis Process. Ten grams (10 g) of the shredded sample was charged into the boiling tubes. The loaded tube was fitted with a wooden cork that allows for the escape of the syngas and a glass trap used to collect the bio-oil generated in the process. The thermometer was inserted into the point designated for temperature measurement and supported by a retort stand. The dried waste recharge card paper is heated in a pyrolysis reactor gradually at the rate of $30^{\circ} \mathrm{C}$ per minute to the temperature of $350{ }^{\circ} \mathrm{C}$ and gas was condensed to liquid containing bio-oil and water. The bio-oil was then separated from water in the mixture and purified by filtration using Whatsman filter paper $45 \mu \mathrm{m}$ mesh size. The purified oil was characterized by physical and chemical properties.

\section{RESULTS AND DISCUSSION}

The physicochemical characteristics of the waste recharge card bio-oil are summarized in Table 1.

Table 1 - Physiochemical properties of pyrolyzed biooil

\begin{tabular}{|c|c|}
\hline Parameters & Bio-oil \\
\hline Density $\left(\mathrm{kg} / \mathrm{m}^{3}\right)$ & 900 \\
\hline Iodine value $\left(\mathrm{gI}_{2} / 100 \mathrm{~g}\right)$ & 22.84 \\
\hline Acid value (mg KOH/g) & 1.122 \\
\hline Free fatty acid (wt.\%) & 0.561 \\
\hline Saponification value (mg KOH/g) & 98.175 \\
\hline
\end{tabular}


The density of the oil determined was $900 \mathrm{~kg} / \mathrm{m}^{3}$ and is lower than the density of vegetable oils $\left(930 \mathrm{~kg} / \mathrm{m}^{3}\right)$ and higher than petroleum $\left(881 \mathrm{~kg} / \mathrm{m}^{3}\right)$. The iodine value obtained was $22.84 \mathrm{gI}_{2} / 100 \mathrm{~g}$ (Table 1) and is relatively low compared to the standard values for most oils ranging between 80 and $106 \mathrm{gI}_{2} / 100 \mathrm{~g}$ [1]. The Iodine value measures the degree of unsaturation in fat or vegetable oil. It determines the stability of oils to oxidation and allows the overall unsaturation of the fat to be determined qualitatively. Generally, oils having iodine value below $100 \mathrm{gI}_{2} / 100$ $\mathrm{g}$ are non-drying, those having values between $100-130 \mathrm{gI}_{2} / 100 \mathrm{~g}$ are semi-drying, and those having values above $130 \mathrm{gI}_{2} / 100 \mathrm{~g}$ are termed drying oils [4]. The greater the iodine value, the more unsaturation and the higher the susceptibility to oxidation.

The acid value and free fatty acid of the pyrolitic oil were $1.122 \mathrm{mg} \mathrm{KOH} / \mathrm{g}$ and $0.561 \mathrm{mg} \mathrm{KOH} / \mathrm{g}$ respectively. Acid value quantifies the fatty acid found in the oil as it measures the free fatty acids (FFA) of oil. The low value obtained shows that the oil is stable and indicates a maximum purity and suitability for soap production [8]. Oil with high acid value implied high \% FFA and will undergo rancidity due to the hydrolysis of the free fatty acids on storage. The low \%FFA reduces the tendency of the oil to undergo hydrolytic activities [3].

The saponification value of the oil was $96.175 \mathrm{mgKOH} / \mathrm{g}$ and is lower than FAO/WHO standard $181.4 \mathrm{mgKOH} / \mathrm{g}$ [1]. This shows that the oil is of lower molecular weight and this property is very important because if it is too high the formation of soap will be more prevalent instead of the desired biodiesel [6]. The saponification value of oil serves as an important parameter in determining the suitability of the oil for soap making.

Table 2 shows a comparison of the fuel properties of the oil and ASTM standard for biodiesel. The density of the oil is within the range of ASTM specification $800-900 \mathrm{~kg} / \mathrm{m}^{3}$. This depicts that the oil can be a raw material for biofuel production. The density of the fuel is an important factor for good engine performance and the higher the density, the more difficult it becomes to pump the fuel. Also, the low value of iodine value (22.84 $\mathrm{gI}_{2} / 100 \mathrm{~g}$ ) obtained shown in Table 1 indicates that biofuel produced from the oil will be better fuel in terms of oxidative stability and cetane number [18].
Table 2 - Comparison of biofuel properties of oil and ASTM Standard

\begin{tabular}{|l|c|c|}
\hline \multicolumn{1}{|c|}{ Parameters } & Bio-oil & $\begin{array}{c}\text { ASTM Standard } \\
\text { for biodiesel }\end{array}$ \\
\hline Density $\left(\mathrm{kg} / \mathrm{m}^{3}\right)$ & 900 & $800-900$ \\
\hline Viscosity $\left(\mathrm{mm}^{2} \mathrm{~s}^{-1}\right)$ & 1.5 & $1.9-6.0$ \\
\hline Pour point $\left({ }^{\circ} \mathrm{C}\right)$ & -15 & -2 \\
\hline Flash point $\left({ }^{\circ} \mathrm{C}\right)$ & 90 & $<130$ \\
\hline
\end{tabular}

The viscosity of the oil is close to the ASTM standard for biodiesel. Viscosity plays an important role in the atomization of the fuel when injected into the combustion chamber. High values of viscosity cause inefficient atomization of the fuel and do not contribute to the formation of a good air-oil mixture (resulting in poor combustion) while low values of viscosity cause an average droplet diameter too small, which decreases the reach of the particles within the chamber, and so part of the oil is not burned [14].

Pour point is the lowest temperature at which the product continues to flow when it is cooling, without stirring. The pour point of the oil obtained ($15^{\circ} \mathrm{C}$ ) is lower than ASTM for biodiesel and higher than petrol diesel $\left(-28^{\circ} \mathrm{C}\right)$ indicating that the performance of the biodiesel in cold conditions will be worse than that of petroleum diesel [6]. The flashpoint of the oil was $90^{\circ} \mathrm{C}$ and is between the value of the ASTM standard for biodiesel $(>130$ ${ }^{\circ} \mathrm{C}$ ) and petrol diesel $\left(90^{\circ} \mathrm{C}\right)$. This will make the biofuel produced from the oil safe for use and storage as fuels with lower flash points tend to ignite at lower temperatures making it highly dangerous if it is not stored and used properly [12].

The GC/MS analysis of the oil in Figure 1 is summarized in Tables 3. Figure 1 shows the peak number and corresponding retention time while Table 3 displayed \% abundance of the various compounds in the oil sample.

Methyl-n-heptanoate, methyl decanoate, and the methyl (10 E)-10-octadecanoate are predominant in the sample with a \% abundance of $29.65,15.6$, and 11.38 respectively.

Methyl tetradecanoate (9.6\%) and methyl butanoate $(9.36 \%)$ are in a moderate amount and are ester compounds. Also, in moderate quantity are alkanes 2,7-dimethyloctane (8.73\%) and 1cosane (8.54\%). 2-butyl-1-octanol (4.63\%), 2(11-methyl dodecoxymethyl) (3.59\%) and 9-octadecenoic acid (3.51\%) are in minor quantity while in trace amount are methyl 3-methyl pentanoate, 13-methyl oxacyclo tetradecane-2,11-dione and 
Methyl decanoate with \% abundance 0.78, 0.60 and $0.48 \%$ respectively. The GCMS revealed the presence of ester, alkanes, alcohol, and carboxylic acid in the oil sample.

The FTIR spectrum of the sample is shown in Figure 2 and the corresponding functional group in Table 4.

Table 3 - GCMS analysis of the pyrolyzed oil

\begin{tabular}{|l|l|c|}
\hline \multicolumn{1}{|c|}{ Name of compound } & \multicolumn{1}{|c|}{ Formula } & $\begin{array}{c}\% \text { Abun- } \\
\text { dance }\end{array}$ \\
\hline 7-ethyl tridecane & $\mathrm{C}_{15} \mathrm{H}_{32}$ & 1.51 \\
\hline 1 cosane & $\mathrm{C}_{20} \mathrm{H}_{42}$ & 8.54 \\
\hline $\begin{array}{l}2(11 \text {-methyl dodecoxyme- } \\
\text { thyl)r }\end{array}$ & $\mathrm{C}_{16} \mathrm{H}_{32} \mathrm{O}_{2}$ & 3.59 \\
\hline 1-acetoxyhexdecane & $\mathrm{C}_{18} \mathrm{H}_{36} \mathrm{O}_{2}$ & 1.84 \\
\hline Methyl n-hexanoate & $\mathrm{C}_{7} \mathrm{H}_{14} \mathrm{O}_{2}$ & 1.12 \\
\hline
\end{tabular}

\begin{tabular}{|l|l|c|}
\hline \multicolumn{1}{|c|}{ Name of compound } & \multicolumn{1}{|c|}{ Formula } & $\begin{array}{c}\text { \% Abun- } \\
\text { dance }\end{array}$ \\
\hline Methyl 3-methylpentanoate & $\mathrm{C}_{7} \mathrm{H}_{4} \mathrm{O}_{2}$ & 0.78 \\
\hline Methyl butanoate & $\mathrm{C}_{5} \mathrm{H}_{10} \mathrm{O}_{2}$ & 9.36 \\
\hline 2,7-dimethyloctane & $\mathrm{C}_{10} \mathrm{H}_{22}$ & 8.73 \\
\hline Methyl-n-heptanoate & $\mathrm{C}_{9} \mathrm{H}_{18} \mathrm{O}_{2}$ & 29.65 \\
\hline Methyl n-heptanoate & $\mathrm{C}_{8} \mathrm{H}_{16} \mathrm{O}_{2}$ & 0.98 \\
\hline Methyl decanoate & $\mathrm{C}_{11} \mathrm{H}_{22} \mathrm{O}_{2}$ & 15.60 \\
\hline Methyl decanoate & $\mathrm{C}_{13} \mathrm{H}_{26} \mathrm{O}_{2}$ & 0.48 \\
\hline Ethyl hexadecanoate & $\mathrm{C}_{18} \mathrm{H}_{36} 0_{2}$ & 0.91 \\
\hline Methyl tetradecanoate & $\mathrm{C}_{15} \mathrm{H}_{30} \mathrm{O}_{2}$ & 9.60 \\
\hline $\begin{array}{l}\text { Methyl(10E) -10- octade- } \\
\text { canoate }\end{array}$ & $\mathrm{C}_{19} \mathrm{H}_{36} \mathrm{O}_{2}$ & 11.38 \\
\hline 2-butyl-1-octanol & $\mathrm{C}_{12} \mathrm{H}_{26} \mathrm{O}$ & 4.63 \\
\hline 9-octadecenoic acid & $\mathrm{C}_{18} \mathrm{H}_{34} \mathrm{O}_{2}$ & 3.51 \\
\hline $\begin{array}{l}\text { 13-methyl oxacyclo tetrade- } \\
\text { cane-2,11-dione }\end{array}$ & $\mathrm{C}_{14} \mathrm{H}_{24} \mathrm{O}_{3}$ & 0.60 \\
\hline
\end{tabular}

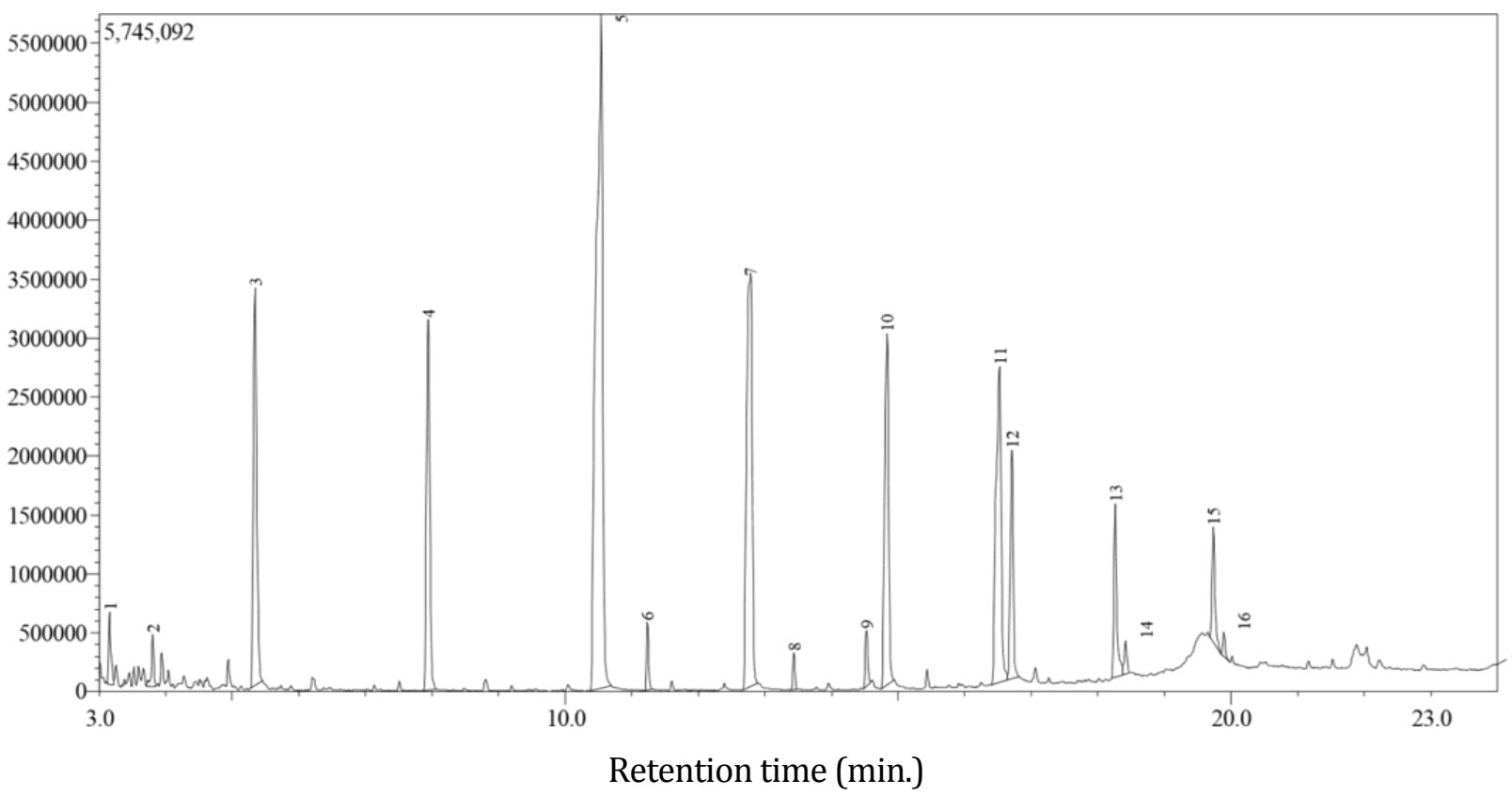

Figure 1 - GCMS Spectra of the pyrolyzed oil

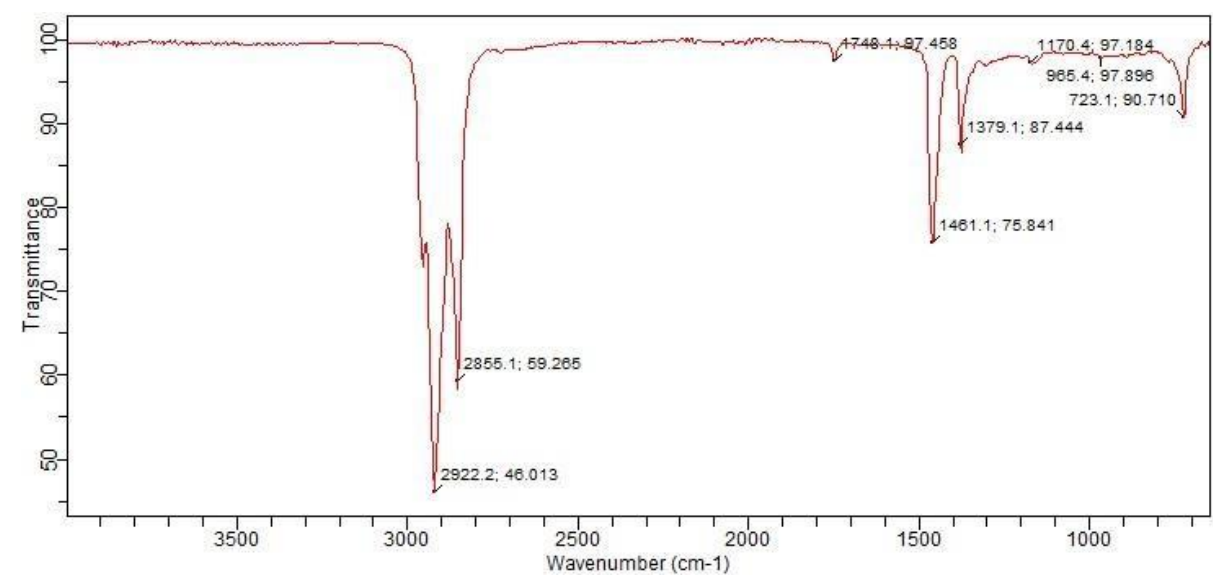

Figure 2 - FTIR of pyrolyzed oil 
The O-H stretching vibration at frequency 2922.2 $\mathrm{cm}-1$ indicates the presence of phenol and alcohol functional groups [16]. The presence of alkane was detected at $2855.2 \mathrm{~cm}^{-1}$ with $\mathrm{C}$-H stretches vibrations. The $\mathrm{C}=\mathrm{O}$ stretching vibration at $1748.1 \mathrm{~cm}^{-1}$ indicates the presence of aldehydes, ketones, carboxylic acids, ester. The presence of alkenes was detected by $\mathrm{C}=\mathrm{C}$ stretching vibration at $1461.1 \mathrm{~cm}^{-1}$.

Table 4 - FTIR of pyrolyzed oil

\begin{tabular}{|c|c|}
\hline Broadband $\left(\mathrm{cm}^{-1}\right)$ & Functional group \\
\hline 1170.4 & Esters \\
\hline 2922.2 & Alcohol \\
\hline 2855.1 & Alkanes \\
\hline 1748.1 & Aldehydes, ketones \\
\hline 1379.1 & Carboxylic acid \\
\hline 1461.1 & Alkenes \\
\hline 765.4 & Phenols \\
\hline
\end{tabular}

The presence of ethers, esters, etc was detected at vibrations stretching $1170.4 \mathrm{~cm}^{-1}$ [20]. The compounds detected by their functional groups summarized in Table 3 are ester, carboxylic acids, alkanes, and alkanes. Others are phenols, ketones, and alcohols as revealed by the GCMS.

Generally, cellulose pyrolysis produces mainly three substances (furans, pyrans, and linear small molecules) and the foremost pyrolysis products include levoglucosan, glycolaldehyde, and 5-hydroxymethyl-furan. The dehydration reaction that is caused by the carbonization of cellulose molecules with increased pyrolysis temperature is indispensable in addition to the depolymerization of cellulose chains and the configuration of various small molecule products [22].

\section{CONCLUSION}

Oil was successfully extracted from waste recharge cards by pyrolysis. The physicochemical and fuel properties obtained revealed its suitability for soap making as well as biodiesel production. The GC-MS and FTIR of the samples also showed the presence of many chemical both linear and cyclo-compounds which have wide industrial applications. Although several promising results were obtained, further investigations including quantitative analyses are necessary to determine the desired characteristics for downstream production of fuels or chemicals as well as improve the bio-oil quality for its utilization.

\section{Competing interests}

The authors declare that there are no competing interests.

\section{REFERENCES}

1. Adegbe, A. A., Larayetan, R. A., Omojuwa, T. J. (2016). Proximate Analysis, Physicochemical Properties and Chemical Constituents Characterization of Moringa Oleifera (Moringaceae) Seed Oil Using GC-MS Analysis. American Journal of Chemistry, 6(2), 23-28.

2. Adekunle, A. S., Oyekunle, J. A. O., Baruwa, S. O., Ogunfowokan, A. O., \& Ebenso, E. E. (2014). Speciation study of the heavy metals in commercially available recharge cards coatings in Nigeria and the health implication. Toxicology Reports, 1, 243-251. doi: 10.1016/j.toxrep.2014.05.008

3. Asanja Alexander, J. (2017). Physicochemical and Phytochemical Characterization of Seed Kernel oil From Desert Date (Balanites Aegyptica). Journal of Chemical Engineering And Bioanalytical Chemistry, 2(1). doi: 10.25177/jcebc.2.1.1

4. Asuquo, J. E. (2008). Studies on the Adsorption of Some Selected Metallic Soaps onto Hematite (Doctoral dissertation), University of Port Harcourt. Nigeria.

5. Biswal, B., Kumar, S., \& Singh, R. K. (2013). Production of Hydrocarbon Liquid by Thermal Pyrolysis of Paper Cup Waste. Journal of Waste Management, 1-7. doi: 10.1155/2013/731858

6. Folaranmi, J. (2013). Production of Biodiesel (B100) from Jatropha Oil Using Sodium Hydroxide as Catalyst. Journal of Petroleum Engineering, 2013, 1-6. doi: 10.1155/2013/956479 
7. Guo, X., Wang, S., Guo, Z., Liu, Q., Luo, Z., \& Cen, K. (2010). Pyrolysis characteristics of bio-oil fractions separated by molecular distillation. Applied Energy, 87(9), 2892-2898. doi:

10.1016/j.apenergy.2009.10.004

8. Haftu, G. A. (2015). Physico-chemical Characterization and Extraction of Oil from Balanites Aegyptiaca Plant (seed). World Journal of Pharmaceutical Research, 4(11), 1723-1732.

9. Hani, F. F. B., \& Hailat, M. M. (2016). Production of Bio-Oil from Pyrolysis of Olive Biomass with/without Catalyst. Advances in Chemical Engineering and Science, 06(04), 488-499. doi: 10.4236/aces.2016.64043

10. Ideriah, K. J. T. (2015). Heavy Metals Concentrations in Mobile Phone Recharge Cards in Port Harcourt Nigeria. International Journal of Current Research and Academic Review, 3(9), 214-220.

11. Jiang, X., Naoko, E., \& Zhong, Z. (2011). Structure properties of pyrolytic lignin extracted from aged bio-oil. Chinese Science Bulletin, 56(14), 1417-1421. doi: 10.1007/s11434-011-4465-4

12. Jock, A. A., Daben, J. M., Yilji, N., Sori, R. M., Ambayin, N. M., Ryemshak, A. S., Mbaya, I. E., \& Putshaka, D. J. (2017). Extraction and Production of Biodiesel from Jatropha Curcas Seed Oil. International Journal of Scientific \& Engineering Research, 8(6), 2046-2049.

13. Lyu, G., Wu, S., \& Zhang, H. (2015). Estimation and Comparison of Bio-Oil Components from Different Pyrolysis Conditions. Frontiers in Energy Research, 3. doi: 10.3389/fenrg.2015.00028

14. Macedo, T., Pereira, G. R., Pardal, M. J., Soares, S. A., \& Lameira, J. V. (2013). Viscosity of Vegetable Oils and Biodiesel and Energy Generation. International Journal of Chemical and Molecular Engineering, 7(5), 251-256.

15. Margallo, M., Taddei, M. B. M., Hernández-Pellón, A., Aldaco, R., \& Irabien, Á. (2015). Environmental sustainability assessment of the management of municipal solid waste incineration residues: a review of the current situation. Clean Technologies and Environmental Policy, 17(5), 1333-1353. doi: 10.1007/s10098-015-0961-6

16. Purakayastha, T. J., Kumari, S., \& Pathak, H. (2015). Characterisation, stability, and microbial effects of four biochars produced from crop residues. Geoderma, 239-240, 293-303. doi: 10.1016/j.geoderma.2014.11.009

17. Roy, M. M., Dutta, A., Corscadden, K., Havard, P., \& Dickie, L. (2011). Review of biosolids management options and co-incineration of a biosolid-derived fuel. Waste Management, 31(11), 2228-2235. doi: 10.1016/j.wasman.2011.06.008

18. Sani, N. J., Aminu, B. M., \& Mukhtar, M. D. (2018). Eco-friendly synthesis of silver nanoparticles using Lactobacillus delbrueckii subsp. bulgaricus isolated from kindrimo (locally fermented milk) in Kano State, Nigeria. Bayero Journal of Pure and Applied Sciences, 10(1), 481. doi: 10.4314/bajopas.v10i1.92s

19. Serrano-Ruiz, J. C., \& Dumesic, J. A. (2011). Catalytic routes for the conversion of biomass into liquid hydrocarbon transportation fuels. Energy Environ. Sci., 4(1), 83-99. doi: 10.1039/c0ee00436g

20. Shah., Z., Veses, R. C., \& da Silva, R. (2016). Using GC-MS to Analyze Bio-Oil Produced from Pyrolysis of Agricultural Wastes - Discarded Soybean Frying Oil, Coffee and Eucalyptus Sawdust in the Presence of 5\% Hydrogen and Argon. Journal of Analytical and Bioanalytical Techniques, 7(2), 17. doi: $10.4172 / 2155-9872.1000300$

21. Sukumaran, R. K., Surender, V. J., Sindhu, R., Binod, P., Janu, K. U., Sajna, K. V., ... Pandey, A. (2010). Lignocellulosic ethanol in India: Prospects, challenges and feedstock availability. Bioresource Technology, 101(13), 4826-4833. doi: 10.1016/j.biortech.2009.11.049

22. Wang, Q., Song, H., Pan, S., Dong, N., Wang, X., \& Sun, S. (2020). Initial pyrolysis mechanism and product formation of cellulose: An Experimental and Density functional theory (DFT) study. Scientific Reports, 10(1). doi: 10.1038/s41598-020-60095-2 
23. Xu, Y., Hu, X., Li, W., \& Shi, Y. (2011). Preparation and Characterization of Bio-oil from Biomass. Progress in Biomass and Bioenergy Production. doi: 10.5772/16466

24. Yang, H., Yan, R., Chen, H., Lee, D. H., \& Zheng, C. (2007). Characteristics of hemicellulose, cellulose and lignin pyrolysis. Fuel, 86(12-13), 1781-1788. doi: 10.1016/j.fuel.2006.12.013

25. Zaman, C. Z., Pal, K., Yehye, W. A., Sagadevan, S., Shah, S. T., Adebisi, G. A., ... Johan, R. B. (2017). Pyrolysis: A Sustainable Way to Generate Energy from Waste. Pyrolysis. doi: 10.5772/intechopen.69036 